\title{
Jury on Stage: A Common Law Play
}

\author{
By \\ Manfred J. Holler ${ }^{*}$ and Martin Leroch ${ }^{* *}$
}

$10 / 04 / 2008$

- Preliminary Version -

\begin{abstract}
Legal processes have a theatrical component to them. They offer an audience - the spectators - and actors - the legal parties, lawyers, as well as the jury and judge - who perform a play on the stage of the courtroom. In this paper we focus on the role of the jury, which appears to simultaneously be audience and actor. As audience, it assures that the power of the judge is limited. As actor, the jury is able to play its role in such a way as to incorporate social attitudes into the verdict. Exploring this theatrical component may shed new light on the debate whether juries are a "good" way of finding legal settlements. Further, it could indicate how legal processes are perceived by the public. As our line of argument builds on Adam Smith's moral and legal philosophy, the analysis may also contribute to the understanding of one of the building blocks of Smith's philosophy, namely the impartial spectator.
\end{abstract}

Key Words: Jury, Legal Proceedings, Adam Smith, Impartial Spectator, Theatre JEL Classification: A13, B12, B30, K40, Z0

\section{Introduction}

Apparently there is something to the theatre beyond merely telling a story. Martha Nussbaum for instance, analyzing the ancient tragedy, found that the way the ancient tragedy was presented, and the topicalities it covered, contributed to the ethical maturation of the society (see Nussbaum 1996). It could do so by tempting the audience to take up the position of the heroes on stage. Accordingly, each observer felt "compassion" with them. That is, the audience felt a certain kind of emotion towards the characters on stage.

Using different terminology, fully enjoying a play seems to presuppose and imply that people empathize with the characters. In fact, this empathetic process seems to be one of the most important aspects of theatre. The spectators face the situations and problems of the main characters themselves, almost as if it were their problems they were actually facing. This introduces the possibility to be confronted with a larger number of decision problems than any

\footnotetext{
* Institute of SocioEconomics, IAW, University of Hamburg, Von-Melle-Park 5, D-20146 Hamburg, Facs: +49 4042838 6329. holler@econ.uni-hamburg.de.

** Institute of SocioEconomics, IAW, University of Hamburg, Von-Melle-Park 5, D-20146 Hamburg, Facs: +49 4042838 6329. leroch@econ.uni-hamburg.de.
} 
individual might be confronted with in his actual life. Also, theatre allows experiencing situations which can hardly ever be met in real life. To give only one example, although (fortunately) only few people are involved in cases of murder, the ancient Greek society was continuously confronted with it by their tragedies. In addition to being confronted with the mere situation, the audience is able to learn how pleasurable ethically correct behaviour can be when watching the behaviour of the heroes - although the heroes, not only in the ancient tragedy, are of course often killed or ostracized as they are burdened with guilt.

Apart from the variety of situations, the mere fact of being tempted to empathize can bear ethical relevance: the audience practices empathizing. This enhances the empathetic abilities within social interactions. According to Nussbaum (1996), both factors, the practice of empathy and the presentation of alternative situations, could have lead to a higher degree of ethical maturation of the Greek society.

Besides empathizing, i.e. taking a different perspective and being involved emotionally, the audience is also invited to form a judgement about the actions performed. In other words, a certain alienation of the audience and the actors is involved as well. Brecht's epic theatre can be considered as polar case concerning the role of such cognitive judgement in the theatre. ${ }^{1}$

Not only the audience learns from the play, but also the actors. However, they do so in different ways. The audience empathizes with the characters on stage, while the actors identify with their roles by acting and reacting. Acting, as opposed to watching, implies a greater degree of "physical involvement" than merely empathizing. Note, however, that the difference between actor and audience can often be blurred. ${ }^{2}$ Nevertheless, for the present purpose it seems sufficient to assume that actors and audience can be treated distinctly.

But theatre is not the only field with theatrical elements. For instance, Ball (1975) analyzes the theatrical aspect of a legal process in front of the court. This, so the author hopes, “may help to clarify its [the courtroom's action] nature and thereby make some small contribution to an understanding of the role of law in our society" (Ball 1975: 82). He finds that "judicial proceedings are themselves a type of theatre" (ibd. 82) which "provide the format of drama" (ibd. 88). Put differently, watching a legal process offers the same potential of ethical maturation as the visit to the theatre, maybe, due to its reality, even greater potential.

A word of clarity seems appropriate before proceeding. In fact, it is not only one play but two we encounter when watching a legal process. The first, the "play in the small" if you

\footnotetext{
${ }^{1}$ Brecht wanted to ban emotions from the stage and only rely on the cognitive abilities of the audience.

2 An example will be given at the end of this paper.
} 
wish, is taking place in front of the jury or a single judge. ${ }^{3}$ The attorneys perform this play in order to convince the jury of their clients' standpoint. As audience of this play the jury finds a verdict. It can do so by letting the jurors employ their empathetic and their cognitive capacities. In other words, both involvement and alienation have to take place on the side of the jurors. The finding of the verdict makes the jury an actor on a bigger stage, on which the "play in the big" is being performed. This play in the big is the legal process in its entirety, the scene we as observers without any role may attend when sitting on the benches for the public. In general, we will in the following focus on the play in the small.

The legal process, the play in the small, provides three theatrical elements: format, space, and audience. The format is, as was found by Ball (1975), that of drama. The element of space can easily be identified as the court room. ${ }^{4}$ The third theatrical element, the audience, is, as introduced above, obviously given by the jury.

One way to look at the jury is to regard it as representation of the society that, among other purposes and effects, is supposed to deal with the ubiquitous vagueness of legal norms. Furthermore, and this gives the link to Nussbaum's analysis, the way in which the jury finds a verdict is due to empathy with other parties of the scenario, namely the defendant and the claimant. However, empathy per se is not sufficient for legal matters. We also need a cognitive component which compares what we have learned by putting ourselves in the others' shoes with our standards of behaviour, i.e. the law and our moral norms of conduct. As noted above, a certain distance or alienation between the empathizer and the one empathized with is necessary for legal decisions. In other words, a specific kind of empathy is necessary. The kind of empathy we have in mind is what Adam Smith called sympathy. We will outline this building block of Smith's moral philosophy in section 3. A second building block is the impartial spectator, which, very roughly, can be regarded as the representation of the public. We will argue that both building blocks play a major role in Smith's legal theory. Actually, his legal theory is closely tied to his moral philosophy, as we will see.

The aim of our analysis is two-fold. On the one hand, we wish to provide further arguments for the discussion about the advantages and disadvantages of the jury as legal institution. Inasmuch as the jury is seen as a constituent element of the common law this is

\footnotetext{
${ }^{3}$ As our aim is to contribute to the discussion surrounding juries, we will in the following only speak of juries.

${ }^{4}$ Interestingly, the physicality of the court room as such seems to play an important role. Ball (1975: 85f.) reports of the attempt to introduce televised processes, thereby altering the physical appearance of the court room. The Chief Justice found that the "physical alteration of the court-room contributed to a substantive alteration of the trial process which could divert it from the fair and reliable determination of guilt to entertainment, commercialization, or political education. ... Thus, if courtrooms are something more than functional locations, this something more is their theatricality - their appropriateness to the singular theatrical action of judicial proceedings. In a word, a courtroom is, following Bentham, a 'judicial theatre' or 'theatre of justice"” (Ball 1975: 85f.).
} 
meant to relieve some of the problems inherent to the question of civil law versus common law. On the other hand, applying the impartial spectator as actor on the stage of legal settlement could serve as a test of Adam Smith's theory and thereby add to our understanding of it. ${ }^{5}$ In order to highlight the proximity of theatre and legal processes, we will in the following section outline a specific Greek tragedy which confronts us with the difficulties of finding a verdict in case that well-justified rights collide, namely Aeschylus' Oresteia. It will serve as reference in the subsequent sections whenever it seems appropriate to illustrate the argumentation with an example.

\section{The Oresteia}

Aeschylus' version of the Oresteia, which is documented in the trilogy Agamemnon, The Libation Bearers and The Eumenides, ${ }^{6}$ illustrates a conflict of rights. In order to solve this conflict, a tribunal of Athenian citizens is founded, which laid the cornerstone of a jury system. But let us start from the beginning.

The story begins just after the fall of Troy. Agamemnon, the commander-in-chief of the victorious Greek troops, paid a high price for his success. In order to defeat the Trojans, he sacrificed his daughter Iphigenia, just as he believed the Gods demanded of him and much to the disapproval of his wife, Clytaemnestra. Apparently his success conceded the sacrifice. Yet, Agamemnon is no flawless hero. In the moment of his triumph, he for a moment loses control of himself. He seizures Cassandra, a priestess of Apollo, and desecrates the Trojan shrines. He even takes Cassandra back to Greece with him, as slave and concubine.

Of course this further arouses Clytaemnestra's anger. But she herself is also far from innocent. While her husband was fighting for Troy, she took Aegisthus, a cousin of Agamemnon's, as lover. However, seeing her husband returning home with a concubine strengthens her belief that she has a right to punish him for sacrificing her daughter and offending herself. She plans to assassinate Agamemnon. For this purpose she manages to lure him into the bath where she kills him with three strokes of an axe, in much the same way as an animal sacrifice is made. As Clytaemnestra says herself: "I strike him once, twice, and at each stroke he cries in agony - he buckles at the knees and crashes here! And when he's down I add the third, last blow, to the Zeus who saves the dead beneath the ground I send that third blow home in homage like a prayer" (Aeschylus 1979: 161).

\footnotetext{
5 For a more general discussion of the relationship between Adam Smith's moral and legal philosophy and some consequences for the design of modern legal institutions, see Holler and Leroch (2008).

${ }^{6}$ Originally Aeschylus had written a fourth part, which is lost unfortunately.
} 
From the point of view of Clytaemnestra, her murder is merely the enforcement of justice. "Here is Agamemnon, my husband made a corpse by this right hand - a masterpiece of justice. Done is done" (Aeschylus 1979: 162). Yet, despite this scene, Clytaemnestra is no blood-thirsty person. Now, as she believes justice to have been enacted, she holds back Aegisthus who was starting a fight with the citizens of Argos, the people of Agamemnon. "No more, my dearest, no more grief. We have too much to reap right here, our mighty harvest of despair. Our lives are based on pain. No bloodshed now" (ibd. 171).

Although Clytaemnestra is not generally blood-thirsty, she murders Cassandra together with Agamemnon. Before she dies, Cassandra, being a seer, foresees that "There will come another to avenge us, born to kill his mother, born his father's champion" (Aeschylus 1979: 155). This prediction already hints towards the fact that Orestes, son of Agamemon and Clytaemnestra, is assigned the role of the avenger. For safety reasons, Clytaemnestra, before she murdered her husband, sent Orestes to the royal court of Phocis, a country of one of Agamemnon's friends, where he is to grow up. By the God Apollo he is now ordered to avenge his father by killing his own mother. "'Gore them like a bull! he [Apollo] called, 'or pay their debt with your own life, one long career of grief"' (Aeschylus 1979: 191). This order faces Orestes with the choice between two evils. Whatever Orestes' choice is, he will have done something wrong; either he will have killed his mother or he will have disobeyed a God. This is the core of his dilemma, which the audience is conducted to take part in.

Orestes chooses to follow the divine order and kills his mother together with Aegisthus. He cuts both to pieces with his sword. But the price he has to pay is high. As Clytaemnestra predicted in her agony, she will haunt him with her Furies. The Furies are multifaceted creatures. On the one hand they are the spirits of the mother, but they are also partly autonomous from her, at times resembling divine creatures. In other parts, they can be described as the conscience of Orestes. Fagles (1979: 22f.) describes the Furies as "a paradox of violence and potential. Snakes in their hair and black robes swarming, they present a real, objective law - blood will have blood - yet that is a law of human nature, too, and the Furies become the pangs of conscience that can lead to self-fulfilment."

Clytaemnestra and her Furies call for revenge. By her death she suffered punishment for the murder of Agamemnon. But her murderer, her own son Orestes, remained unpunished. Having called for the assassination, Apollo supports Orestes in his struggle against the Furies. He throws the Furies out of his temple, but still they haunt Orestes. Orestes heads for Athens in order to plead Athena for forgiveness. However, the case is too complicated for Athena in order to find a fast and clear verdict. Her choice resembles that of Orestes. Either she incites 
the Furies by setting Orestes free, or she incites one of the gods by convicting his servant. "So it stands", she summarizes, "A crisis either way. Embrace the one? expel the other? It defeats me" (Aeschylus 1979: 253).

Instead of ruling the case all by herself, Athena decides to gather "the finest men of Athens" (ibd.) in order to judge about Orestes. This assembly, the first formal jury, is the Areopagus, which then turned to be the establishment of the rule of law, "a tribunal here for all time to come" (ibd.). But before this can happen, the jury faces the difficult choice between punishing matricide and respecting the murder as obedience to Divine order. The decision of the jury highlights the severity of what is at stake. After a legal process in which Apollo defends Orestes and the Furies accuse him, it turns out that the lots are equal. Only at this point in time Athena finally decides that "The man goes free, cleared of the charge of blood" (ibd. 265).

It should be noted that there is a debate on whether the number of lots is equal before Athena passes her ballot-stone or afterwards. Before the ballots are counted, Athena tells Orestes that she will cast her lot for him. Also, the director-instructions say that she is "Raising her arm, her hand clenched as if holding a ballot-stone" (ibd. 264). But if the votes were equal after her ballot has been passed, her vote would weigh more than the others'. However the case may be, Fagles (1979, note to line 767) "prefer[s] to believe that the number of jurors is even, that they may be deadlocked five to five [...] and that Athena's ballot may simply break the tie." With the acquittal of Orestes Aeschylus' version of the Oresteia ends.

\section{The Concept of Sympathy in Smith's Moral Philosophy}

When watching the Oresteia or some other tragedy on stage, we are in most cases emotionally involved to a certain degree. Some part of the story usually moves us. In other words, we identify with the actors on stage; we feel what they feel, at least partly. This "feeling with" was termed sympathy by Adam Smith. In the Theory of Moral Sentiments (TMS) we can read that "[p]ity and compassion are words appropriated to signify our fellowfeeling with the sorrow of others. Sympathy, though its meaning was, perhaps, originally the same, may now, however, without much impropriety, be made use of to denote our fellowfeeling with any passion whatever" (TMS I.I.5). This definition refers to what might be called weak form of sympathy. In this meaning, sympathy is merely an ability, as opposed to an evaluation or judgement. That is, one imaginatively changes positions with the other. But this 
does not necessarily mean that we derive any judgements or emotions from this change of positions.

However, Smith sometimes "smuggles in" a different meaning; something that might be called the strong form of sympathy. "To approve of the passions of another ... as suitable to their objects, is the same thing as to observe that we entirely sympathize with them; and not to approve of them as such, is the same thing as to observe that we do not entirely sympathize with them" (TMS, I.i.3.1). Here, sympathy corresponds to the evaluation of the other's behaviour after having put oneself into his position. In this meaning, sympathy may sometimes, though not necessarily, be accompanied by emotions or sentiments. Yet, the two forms of sympathy are closely connected as the strong form of sympathy presupposes the weak form of it. Without an imagined change of situations there can be no approval of the other's passions. We "empathize" with Orestes, to use Nussbaum's terminology, before we feel "compassion" with his decision and "feel" that he did correctly - or not. In the following subsections we will further analyze the role both forms of sympathy play in Smith's philosophy.

\subsection{Gaining Information}

Leaving aside further details about different notions or forms of sympathy in Smith, ${ }^{7}$ it seems worth emphasizing that the basic function of sympathy in its weak form is to get a clear picture of the position of the other. We gain information about the situation of the person we sympathize with. Put differently, sympathizing tells us a story - namely the story of the one we sympathize with. We perform an imaginative play by sympathizing. We imagine how it would feel being in the other's position. 'Indeed, to 'substitute' (to use a term from drama) one's experiences for another's, in the way that an actor on the stage does for a character when trying to get inside that character's emotional life, has as its goal the accurate representation of that character. It assumes a difference between arbitrary reconstruction and true interpretation. One has to know what experiences to substitute, how, and when" (Griswold 2006: 33).

Performing this play also implies to take a broader perspective, as we now see things from different points of view. As Griswold (2006: 26) points out, in Smith's theory "[t]he sympathetic imagination is not solely representational or reproductive. It is primarily narrative, seeking to flow into and fill up another situation, and to draw things together into a coherent story, thus bringing the spectator out of him- or herself and onto the larger stage. All

\footnotetext{
${ }^{7}$ For a further discussion of these notions, see e.g. Haakonssen (1981: 51), Griswold (1999), Holler (2006), or Sutrop (2007).
} 
this holds whether we are observing real persons or actors in the theatre." Watching Orestes' actions on stage, we not only see the setting with the eyes of the audience, but we also see it with his eyes and the eyes of the other actors. Griswold (2006: 26) concludes that Smith implies "that our sympathizing with imagined characters is the same kind of process as our sympathizing with 'real' people in everyday life. This is one reason why drama and literature not only provide Smith with examples that nicely illustrate the workings of the imagination, but on his account are also important to our moral education. Drama and literature are central to ethics (in particular, to moral education) because the sympathetic imagination is so important to the accurate 'understanding' of others and to the formation of ethical judgment." 8

Apparently, the importance of sympathy in its weak form is to prepare us for an evaluation of actions from an ethical point of view. According to Smith, we have to gain as much knowledge as possible of the action and its consequences before we can find a verdict. Hence, we first of all have to sympathize (sympathy in its weak form) with the person being acted upon and with the one acting. By sympathizing with the former, the one acted upon, we can find out about the "damage" that has been done. By sympathizing with the latter, the actor, we can find out about the motives which drove the action. These motives are important because, according to Smith, the propriety of an action is determined by them. For instance, we have to consider what drove Clytaemnestra's assassination. If we merely considered the murder without taking account of the Divine order (and the reasons for this order) Orestes would surely be convicted. But, knowing the bigger picture, this would somehow strike our "intuition" as being wrong.

Both cases of sympathy, i.e. sympathy with the actor and the one acted upon, are important for a "fair" evaluation of actions, again, as we want to get a clear picture of what is going on. That is to say, we want to know "why what happened to whom." By sympathizing with the actor we find out why something happened, i.e. the motives for the action. We find out "what" happened via sympathy with the one acted upon.

\subsection{Evaluating Actions}

So far only sympathy in its weak form was necessary. When it comes to evaluate the situation, sympathy in its strong form comes to play. "The whole drive behind all sympathizing is, as we shall see, a basic wish to relate or compare our own reactions to those of others. It is only this 'tension' between persons that gives rise to all evaluations of persons, of which the act of sympathy is the necessary first step" (Haakonssen 1981: 48f.). After we

\footnotetext{
${ }^{8}$ Nevertheless it should be mentioned that Smith was not always strongly in favour of supporting real-world theatre groups.
} 
have sympathized in the weak form, i.e. have seen the situation from the other's point of view, we can now consider whether or not we agree with the actions of those we have sympathized with. This agreement will be reflected by our "degree" of sympathy - sympathy now understood in its strong form or by other forms of reaction. The information we gathered via the changing of positions may influence the way we "feel" about the other's actions and how we react on them. In some instances this may lead to approval, in others to rejection. That is, we somehow "feel" and "understand" that Orestes' decision was the right one, possibly because we can imagine having acted in the very same way. Sometimes the story "touches" us, in which case we may feel either strong approval or reprobation, and sometimes we will be puzzled, irritated and paralyzed.

Just as we have to put ourselves both in the shoes of the actor and the one acted upon, we can now evaluate both the action and the reaction of those people directly involved. Both the evaluation of action and reaction seems important for Smith, because he notes that "[a]s our sense, therefore, of the propriety of conduct arises from what I shall call a direct sympathy with the affections and motives of the person who acts, so our sense of its merit arises from what I shall call an indirect sympathy with the gratitude of the person who is, if I may say so, acted upon" (TMS, II.i.5.1, italics added). In "order that sympathy should function as a condition and within the ambit of a moral evaluation it is necessary to pass from direct to indirect sympathy" (Bagolini 1975: 105).

When we, as observers, find that we cannot sympathize with someone's actions, Smith argues, we immediately have an emotional reaction towards the actor. Consider for instance the case in which somebody was hurt by somebody else. Assume that by placing ourselves in the position of both parties we cannot find any justification (or reasonable excuse) for the action that caused the other's suffering. Hence, we consider the motives for action as being improper, as Smith would say. In this case, we would develop a desire to see the actor punished for causing the harm. In Smith's own words, "when the hurtfulness of the action is joined the impropriety of the affection from whence it proceeds, when our heart rejects with abhorrence all fellow-feeling with the motives of the agent, we then heartily and entirely sympathize with the resentment of the sufferer." And Smith continues: "Such actions seem then to deserve, and, if I may say so, to call aloud for, a proportionable punishment; and we entirely enter into, and thereby approve of, that resentment which prompts to inflict it" (TMS, II.i.4.4).

Note that agreement, understanding and approval include a cognitive element. Hence, Smith's conception of sympathy (in its strong form) also includes a rational component (see, 
e.g. Khalil 2007: 13f.). As Levy and Pearl (2004: 336) put it, "Smith holds that sympathy is akin to an estimation procedure in which we imaginatively exchanging positions while preserving our consciousness."

Punishment implies that we approve of the resentments of the sufferer. But it also means that we approve of the sentiments of the one punished. First, however, Smith makes clear that the "offender necessarily seems then to be the proper object of punishment, when we thus entirely sympathize with, and thereby approve of, that sentiment which prompts to punish. In this case too, when we approve, and go along with, the affection from which the action proceeds, we must necessarily approve of the action, and regard the person against whom it is directed, as its proper and suitable object" (TMS, II.i.4.4).

We may argue that only if we can compare the resentments of the sufferer and the sentiments of the punished offender, we can assure the proportionality of punishment. To put resentments and the sentiments of punishment "on legal stage" could help to clarify if punishment is appropriate and, in case it is, to what degree. We might for instance see that not all offenders are the proper object of punishment. A policeman who "did his duty" and thereby offended a citizen who transgressed a legal rule is an obvious exception.

The motives that drove Orestes to kill his mother were Divine order and avenge for the murder of his father. Considering this fact alone makes his action proper, i.e. Orestes has a good reason we can understand. But Clytaemnestra answers her death not by gratitude but by haunting Orestes with her Furies. Obviously, Clytaemnestra cannot sympathize with Orestes' motives - and (possibly) neither can we, if we see things from her point of view alone. This makes Orestes' action culpable. This tension between propriety and demerit gives rise to the dramatic core of the story. Apparently, morality alone will not give us a solution, viz. a clear verdict. And even the Goddess Athena first has to establish the Areopag in order to find a clear answer.

\section{From Moral to Legal Philosophy}

In Adam Smith's moral philosophy judgements are mainly about moral worthiness of actions. But the introduction of "punishment" allows Smith to export his idea of sympathy and make it the basis of his legal theory. By doing so, Smith also implicitly addresses a different issue: There is no "natural" borderline between "process of applying morality" and the "process of applying the law." In fact, "[i]t is interesting to see how and in what senses the sympathetic process, as outlined by Smith, is applicable to the decision of a judge" (Bagolini 1975: 103). The law seems to follow morality in certain respects, as can be illustrated by the 
Areopag. It has no legal guidance at all in finding its verdict. The jurors can only rely on their morality. And out of the "combined morality" of all jurors the law will evolve.

Although given guidance by legal procedures and norms, any judge will also have to sympathize with the legal parties in order to find out what happened. By sympathizing, he may come to the conclusion that one party was (unrightfully) affected in a negative manner, viz. injured. Thus, as Haakonssen (1981: 100) observes, the concept of injury connects Smith's moral and legal philosophy: "The concept of 'injury' is understood in pure spectatorterms: what the relevant, actual spectators - such as judges and juries - in a given society recognizes as injury is in legal terms injury in that society at that time and is definitive of its rights and laws. And what the impartial spectator recognizes as injury is definitive of absolute rights and justice. This is never spelt out in so many words, but is simply taken for granted throughout, and it is indeed abundantly clear once we analyse Smith's concrete uses of the central concepts."

The importance of sympathy for legal aspects, especially crime, is highlighted in Smith's further elaboration on Jurisprudence. It appears that punishment is mainly driven by the resentment of those affected and the sympathy of those who have the power to punish in their stead (see LJ, 485). In general, however, Smith distinguishes three reasons for punishment, namely "sympathy with the resentment of the sufferer, or from public utility, or to satisfy the public" (LJ, 484, italics added). Note that Smith speaks of "public utility", which could be paraphrased with "public security" or "social protection". However, Smith is very explicit for the "natural measure of punishment" that "it cannot be utility" (LJ, 475), i.e. the kind of welfare-based utility being used in standard Law \& Economics. ${ }^{9}$ Of the reasons for punishment, only the "emotional reasons" account for the wish to punish criminal behaviour. "But though it commonly requires no great discernment to see the destructive tendency of all licentious practices to the welfare of society, it is seldom this consideration which first animates us against them. All men, even the most stupid and unthinking, abhor fraud, perfidy, and injustice, and delight to see them punished. But few men have reflected upon the necessity of justice to the existence of society, how obvious soever that necessity may appear to be" (TMS, II.ii.3.9).

Implicit in these arguments is that a crime is affecting not only the direct sufferer, but the public as well. According to Smith, a crime can be "considered in two lights, as committed against the family injured and against the peace" (LJ, 477). In a similar manner, the sacrifice of Agamemnon's daughter - a crime from the point of view of Clytaemnestra -

\footnotetext{
${ }^{9}$ According to Bagolini (1975: 108), this fact distinguishes Smith from Hume. For Hume the utility or "usefulness" is the principle according to which we provide moral approval. For Smith it is the propriety.
} 
also had an important effect on the public. If one believes in divine signals (and their correct interpretation), this crime helped the Greeks defeat the Trojans.

Further, as we have seen, punishment for crime is thought to satisfy resentments. The punishment is supposed to make us feel good and make the punished aware of the fact that he did something wrong. "Resentment not only prompts to punishment but points out the manner of it. Our resentment is not gratified unless the offender be punished for the particular offence done ourselves, and unless he be made sensible that it is for that action. A crime is always the violation of some right, natural or acquired, real or personal" (LJ, 475f.).

That punishment is not only to satisfy the resentment of the sufferer, but the resentment of the society as a whole becomes clear in Smith's elaboration on the case of murder. "The greatest crime that can be done against any person is murther, of which the natural punishment is death, not as a compensation but a reasonable retaliation. ... When government became more powerfull, the murtherer was not only obliged to make a compensation to the relations of the slain, but likewise to the publick, who were put to the trouble of lending him their protection on that occasion, against the revenge of those who were concerned" (LJ, 475f.). ${ }^{10}$ This implies that both the sufferer and the society are affected and that even the society, "the publick", will show something like "sentiments" and feel resentments. Thus, the appearance of negative sentiments, both on the side of the direct victim and on the side of the not directly affected public, seems to be the prime driving factor behind punishment.

\section{Proportional Punishment and Impartiality}

Of course only a minority of legal trials deals with murder in marriage or matricide as the Oresteia does. Finding the correct verdict for the majority of less severe cases may often prove more complicated. But, in principle, the above findings apply to all cases, severe or not: If an action caused harm as well as resentments and the intention for this action was improper, the actor is to be punished. Further, our immediate reaction would call for "proportionable punishment" or a "natural measure of punishment." What constitutes this measure is so far not clear. In the Lectures on Jurisprudence we can read more about the proper degree of punishment. "Injury naturaly excites the resentment of the spectator, and the punishment of the offender is reasonable as far as the indifferent spectator can go along with it. This is the natural measure of punishment. It is to be observed that our first approbation of punishment is not founded upon the regard to public utility which is commonly taken to be the foundation of

\footnotetext{
10 Note that in the case of murder the sufferer is not present anymore. However, this does not prevent us from sympathizing with him, as we can sympathize even with the dead (see TMS I.i.1.13).
} 
it. It is our sympathy with the resentment of the sufferer which is the real principle" (LJ, 475f.). Obviously, imaginatively placing ourselves in the position of the sufferer and approving of his resentment, i.e. sympathy (in its strong form), brings us to the conclusion that there is "something wrong". This provides the basis, our "first approbation of punishment", in the sense that we now agree that someone has to be punished because someone else has been done wrong. Therefore sympathy (with the sufferer and his resentments) is "the real principle" for punishment. ${ }^{11}$

\subsection{Proper Degree of Punishment}

In order to know what degree of punishment is adequate, we have to abstract from the immediate resentment of the sufferer and our own as spectator. We have to call for the position of the indifferent spectator: someone who is not directly involved in the situation to be judged of. In Adam Smith's moral philosophy the indifferent or impartial spectator represents a second building block, besides sympathy. He is "the man within the breast" (see, e.g., TMS, III.2.32-33, and III.3.26+28+29), a synonym for one's conscience. For instance, it is he who tells us which action is worthy of praise or blame. The focus on the worthiness of praise or blame, as opposed to actual praise and blame is important, because "by pleasing one man, we ... disoblige another" (Raphael 1975: 91). We avoid this conflict exactly by focussing on the worthiness of an action of which the "man within the breast" informs us.

In order to find out about the impartial spectator's judgment, we have to sympathize with him. That is, we place ourselves in the shoes of an imagined person. Therefore, one can say that moral self-consciousness requires that I "divide myself, as it were, in two persons" (TMS, III.1.6), namely the impartial spectator and my actual self. We can do so if "our sympathizing with imagined characters is the same kind of process as our sympathizing with 'real' people in everyday life" (Griswold 2006: 26). Smith argues that we are powerless against this tendency to sympathize with e.g. actors on stage, even if we don't want to, as the following passage indicates. "When we attend to the representation of a tragedy, we struggle against that sympathetic sorrow which the entertainment inspires as long as we can, and we give way to it at last only when we can no longer avoid it" (TMS I.iii.1.9).

\subsection{Distortions of Punishment}

The reason why impartiality plays such an important role lies in the fact that punishment is grounded on sentiments. These sentiments are likely to distort our evaluation of

\footnotetext{
${ }^{11}$ Once again, this is apparently the reason why it is important that we can sympathize even with the dead (see
} TMS I.i.1.13). 
an action in the immediate moment of their cause. According to Smith, we evaluate our actions in two different situations. "First, when we are about to act; and secondly, after we have acted" (TMS, III.I.89). In principle, both evaluations should involve the perspective of the impartial spectator. However, the passions of mankind make it (almost) impossible to evaluate actions in a similar manner before and after they have been conducted. "When we are about to act, the eagerness of passion will seldom allow us to consider what we are doing, with the candour of an indifferent person" (TMS, III.I.89). But, "[w]hen the action is over, indeed, and the passions which prompted it have subsided, we can enter more coolly into the sentiments of the indifferent spectator" (TMS, III.I.91). This implies that sentiments need some time to "mature" in order to become "reasonable" and "understandable" for others and others can sympathize with them. As Khalil (2007) puts it, Smith's introduction of both sympathy and the impartial spectator represents a "break pedal" for our sentiments. Sympathizing and calling on the impartial spectator attenuates our sentiments.

Grounding punishment on our immediate sentiments, without calling on the impartial spectator, would thus distort the punishment. Introducing an impartial instance may level out the distortions created by sentiments and hence offer the opportunity of a maturing society, in which only the "correct" infringements are punished "correctly". Apparently, a main advantage of a well-organized society with a legal court system is that it is able to level out extreme reactions.

A further source of distortion lies in what we in fact evaluate. For Smith actually only the propriety, viz. the motivation, and the merit of an action, i.e. its effect on the one acted upon, should play a role. But in fact, the actions per se may, as Haakonssen (1981: 65) puts it, "steal the show" (see e.g. TMS, II.iii.1.7). It could well be that people convict Orestes on the grounds of the mere action of killing his mother, without asking for his motivation, the order of Apollo. Again, just as it is the case with the distorted sentiments, the conflation of motives and actions may lead to a distortion of the verdict. "This bias in all judgements of propriety is, naturally, communicated by means of mutual sympathy throughout any social group. Hence it is that although the ideal objects of our moral judgements are motives and intentions, the actual objects are often actions and their consequences" (Haakonssen 1981: 65) that trigger sentiments and resentments.

\subsection{Who Should Punish?}

Initially, it seems, it is up to the victims to hold the delinquent responsible. That is, whenever the right of someone is infringed, this creates a right to redress on the side of the 
victim. Furthermore, this right is directed towards the one who infringed the initial right. "The legal recognition that an action against a person is an injury is based upon the impartial spectator's sympathy with the resentment of that person, and the right to seek redress is therefore also based upon that spectator sympathy. It is, however, not only the right to seek punishment, but also the right to seek a particular degree of punishment which is dependent upon the approval of the impartial spectator" (Haakonssen 1981: 114).

Apparently, if the victim himself takes revenge for some injury or calls for redress, he will tend to redress "too much" as compared to the standard of the impartial spectator. He, as the direct sufferer, will have strong sentiments against the wrongdoer. In order to overcome this problem of excessive punishment, an impartial "third party" executing the punishment, may be introduced and improper sentiments thereby excluded.

Seemingly, the mere fact of treating a case in front of a court already helps to introduce an impartial perspective and control resentments. "The theatrical character of lawsuits allows them to redirect aggression. Aggression, the need to fight and have revenge, is acted out and thereby ritually expressed and controlled. It is in this sense that ' $[\mathrm{t}] \mathrm{he}$ right to sue and defend in the courts is the alternative of force"” (Ball 1975: 107). Being able to take an impartial perspective then helps the court to secure justice. "Courts may not always or even frequently do justice, but their theatrical quality does contribute to their potential for doing justice by encouraging disinterestedness in the decisionmakers. Actors, judge and jury are asked to play parts in a government of laws and not of people. They are to be those who decide according to law. Fulfillment of the roles enables judgements which rise above prejudice and which, therefore, will more likely be just" (ibd. 101).

\section{The Jury as Representation of the Impartial Spectator}

Paraphrasing the impartial spectator with our conscience already indicates that he is a rather influential character. At least he is so for a person of real constancy and firmness who "has never dared to forget for one moment the judgment which the impartial spectator would pass upon his sentiments and conduct. He has never dared to suffer the man within the breast to be absent one moment from his attention" (TMS, III.3.25). Constantly acting under the eyes of the impartial spectator actually defines a man of real constancy and firmness. This implies that the impartial spectator is the personification of values, of norms of behaviour. "The impartial spectator has normative force in part because it defines the moral point of view already latent in ordinary life. ... The 'precise and distinct measure' of virtue is to be found in the 'sympathetic feelings of the impartial and well-informed spectator"' (Griswold 2006: 39). 
It is important to note that Adam Smith's impartial spectator is built up and influenced by the society surrounding him. In fact, he can be interpreted as representative of and "standin" for this public. "When I make a moral assessment of someone's motive or feeling, according to Smith, I express a sympathy with it that I expect any one (of us) to share. I impartially project myself into that person's standpoint, not as myself but as any of us, and (attempt to) judge what any of us would be moved to do or feel if in that person's shoes" (Darwall 1999: 160).

Therefore, the impartial spectator not only tells us what we should do. He forms our expectations of what others are supposed to do. Put differently, the impartial spectator can be interpreted as epitome of the society's value system. "It is in this light that I suggest we see Smith's idea of the impartial spectator. When we strive towards his standpoint we are in reality seeking the position which is most widely compatible with existing values, the position which fits the moral context. ... So it would seem that when we judge of the moral value of an action we consider whether it is in accordance with a general rule and whether the type of action prescribed by this rule is generally compatible with existing values" (Haakonssen 1981: 62).

The impartial spectator defines what could be called the social perspective on a case under consideration. But in fact, the perspective of the impartial spectator is more than just a "position." It develops normative force, as was found above. It is that kind of behaviour we want to see enacted, which we "feel" is right. This way of looking at the impartial spectator gives the link to the sentiments and to sympathy, which were discussed in the previous sections.

And yet again we find a close resemblance of Smith's moral philosophy with his legal philosophy. When it comes to legal decisions, the perspective of the society on a specific case may gain great importance. Firstly, legal rules are always abstract and vague and can therefore not be applied to a specific case without difficulty. According to Hart (1958: 607) "a penumbra of uncertainty must surround all legal rules", and therefore "their application to specific cases in the penumbral area cannot be a matter of logical deduction ... And it follows that if legal arguments and legal decisions of penumbral questions are to be rational, their rationality must lie in something other than a logical relation to premises.” Orestes' case may serve as vivid example for such a penumbral area. No unambiguous verdict can be found immediately. Once again, on the one hand he followed divine order; on the other hand he violated a moral standard by committing matricide. 
Secondly, if a legal rule is not supported by the society, its enforcement may be rather difficult - except possibly for cases of severe punishment. But even then the severness of punishment could be regarded as improper and induce unintended consequences. For instance, imposing the death penalty for the stealing of apples would probably be regarded as too strict in most western societies and arouse social opposition. ${ }^{12}$

The jury is an institution that may assure that the perspective of the public is respected, at least partly. This seems to be part of the reason for Athene to call in the Areopag, an assembly that consisted of "the best Athenians" (Fagles 1979: 78). Clearly such a noble jury is not available for every earthly trial. At this point of argumentation, the jury may be regarded as more or less random selection of people from the society. As such it may help to find the "social understanding" of given legal rules and the cases to be judged. That is to say, the jury approximates what the society as a whole regards as the social standards for the case under consideration if unbiased. In a (legal) judgement process, as described by Adam Smith, each member of the jury has to individually and impartially sympathize with the parties in the court thereby assuring that they will be respected equally. Via sympathy biases of the parties are levelled out and an impartial position can be approximated.

However, as mankind is not perfect, the jurors may tend to give the parties different weights, thereby distorting their personal verdict. In other words, impartiality may be impossible to achieve for the individual jurors. ${ }^{13}$ Communication among the jurors may help to overcome these individual biases. Rawls (1972: 358), for instance, found that "in everyday life the exchange of opinion with others checks our partiality and widens our perspective." Additionally, even if the individual jurors remain partial to some degree, the jury as a whole may reach an impartial verdict if communication is allowed. "The great pleasure of conversation and society ... arises from a certain correspondence of sentiments and opinions, from a certain harmony of minds, which, like so many musical instruments, coincide and keep time with one another. But this most delightful harmony cannot be obtained unless there is a free communication of sentiments and opinions. We all desire, upon this account, to feel how each other is affected, to penetrate into each other's bosoms, and to observe the sentiments

\footnotetext{
12 This of course does not rule out that a system of terror may suppress social opposition. History is full of examples. What we like to point out is that there are other ways, cheaper in terms of enforcement costs, that provide the same level of silence on the streets.

13 It seems important to note that the "misunderstanding" of a single juror or judge concerning this social aim is not necessarily the result of a bad intention. "A judge has to apply a rule to a concrete case ... He either does not see or pretends not to see that the general terms of this rule are susceptible of different interpretations and that he has a choice left open uncontrolled by linguistic conventions. He ignores, or is blind to, the fact that he is in the area of the penumbra and is not dealing with a standard case. Instead of choosing in the light of social aims, the judge fixes the meaning in a different way" (Hart 1958: 610f.).
} 
and effections which really subsist there" (TMS, VII.iv.28). Haakonssen (1981: 171) comes to conclude that it "is hardly surprising that the philosopher of impartial spectating should stress the importance of another product of the early strength of the English courts: the jury system. The feature of the modern jury which Smith emphasizes is exactly that it is likely to function as an impartial observer." Therefore, moral sentiments allow stage the impartial spectator as a jury when it comes to making legal decisions.

Seen in this light, the vagueness of legal rules turns into an advantage as it helps to extract their "true meaning" for a given point in time. "[I]nstead of saying that the recurrence of penumbral questions shows us that legal rules are essentially incomplete, and that, when they fail to determine decisions, judges must legislate and so exercise a creative choice between alternatives, we shall say that the social policies which guide the judges' choice are in a sense there for them to discover; the judges are only 'drawing out' of the rule what, if it is properly understood, is 'latent' within it" (Hart 1958: 612). The judges or the jury are able to identify the meaning of a specific rule for a specific condition of the society exactly because the legal rule is vague. In this sense, the judges or the jury resemble directors of a play who draw out the specificities of the stories that touch the society in this moment in time. Shakespeare will always touch us to a certain degree. But a specific performance, given meaning by the director and the actors, may even enhance its effect if well done.

If the society influences the judicial system, having a close look at the play offered sheds light on the organization of society as a whole. "Judicial theatre, then, holds up a mirror to legitimate society insofar as the courtroom is the locus for trying on, trying out and proving personae juris. It images lawful political community. Accordingly, trial practice may serve as a measure of the out-of-court conduct of nonjudicial officials, such as the police" (Ball 1975: 110).

\section{Some Limits to the Application of the Jury}

In the light of what has been said in the previous section, it seems odd that juries are not more widely applied than they are. Moreover, it even seems peculiar that the jury in general does not decide on the degree of punishment itself. The answer to these puzzles, we believe, mainly lies in the fact that the application of the jury in the real world faces difficulties which have so far been ruled out in our abstract analysis. It is not the case that the scripts or the theatre play per se are bad - but the actors (or the director) may be worth improvement. Athena, in choosing the jurors for the Areopag, seemed to have been aware of 
the necessity of "good" jurors. "These will be men and gods together - the best Athenians, with Athena as their leader" (Fagles 1979: 78).

To enlighten the problem of adequate representation we may apply the Condorcet Jury Theorem. It states that "if each individual is somewhat more likely than not to make the 'better' choice between some pair of alternatives and each individual has the same probability of being correct in this choice, then the probability for the group majority being correct increases as the number of individuals increases" (Grofman and Feld, 1988: 569).

The original version of the Jury Theorem presupposes independence among the jurors. However, Berg (1993) has shown that, from a theoretical point, dependence among jurors need not yield the Jury Theorem inapplicable. Yet, crucial for its applicability is negative correlation between the voters. That is, some people will always vote "yes" if others vote "no". Applied to a jury in the real world, this would mean that some people will always have the opposite opinion of each other. Although this need not be impossible, it seems highly questionable whether this case is the rule. Actual evidence even seems to point to the opposite. For instance, Sunstein (1999) found (in a non-legal setting) that groups whose members where allowed to communicate may polarize. This means that the opinions within a group tend to move towards one extreme opinion within the group. Put differently, the attitudes within the group are in fact not very likely to show negative correlation. Further, by allowing communication, the most extreme opinion tends to be pushed into an even further extreme - at least in cases of judgement of values, as opposed to judgements of fact.

It seems as if two effects distort the attitudes of the individuals in this case, especially if the group finding the judgement is rather homogeneous from the outset. Firstly, as the group is homogeneous, only a limited amount of attitudes is represented. Accordingly, a "good deliberation process" is prevented by a "limited argument pool", as Sunstein (1999: 4) observes. Communication, which was introduced above as means to overcome partiality, is unable to fulfil this goal in case of homogeneous groups, as the additional information transmitted is not "new"; it does not contribute to a levelling of biases. To the contrary, communication now turns out to have a deteriorating effect. Furthermore, people may adapt their opinion to the one of others if that other opinion is shared by the vast majority of people. This might even be the case if the others' opinions are wrong. If " $\mathrm{A}$ and $\mathrm{B}$ believe that fear is justified, $\mathrm{C}$ may end up thinking so too, at least if she lacks independent information to the contrary" (Sunstein 1999: 8).

Secondly, reputation mechanisms may play an important role for the individuals' actions and judgements within a group. "[T]he basic idea is that people care about their 
reputations, and they speak out, or remain silent, or even engage in certain expressive activity, partly in order to preserve those reputations, even at the price of failing to say what they really think" (Sunstein 1999: 4). In other words, people often like to see themselves as taking a specific position relative to others. As long as nobody communicates his or her position, everybody takes the attitude he believes to be in the aspired position relative to the others' attitudes. If, after people have communicated among each other, they then observe that, in reality, they do not occupy this position, they tend to change their (expressed) attitudes far enough in the hope to reach the aspired relative position to others in the reference group. The fear of polarization could provide good reason not to give juries the power to decide on the degree of penalty.

If the group is very homogeneous, the effects described above, i.e. the effects of a limited argument pool and reputation mechanisms, may come to play. However, it as well appears to be the case that in order to achieve a "good communication", a certain degree of homogeneity is indeed required. For instance, Sunstein (1999: 15) observers "good" deliberation "when people perceive fellow members as friendly, likable, and similar to them." In a similar manner, anonymity among group members seems to decrease the amount of information passed to others and thereby hinders deliberation. Moreover, the existence of clearly defined outgroups, i.e. groups distinct from one's own, may favour "good deliberation" within a group as well.

These observations can be interpreted in the way that the ability to sympathize with other members of the group plays a crucial role for reaching a common point of view. Sympathy (in the strong form) can be regarded as rendering the one sympathized with as likeable and similar to oneself. Respecting the fact that we can never fully take the perspective of the other, but will always have to imagine parts of this perspective, we can say that we will have to "imagine more" in cases in which we are very different from each other as compared to those in which we are similar. Thus, the "cognitive effort" necessary to reach a common standpoint or mutual understanding is increased. ${ }^{14}$ If the viewpoints of the group members are similar from the outset, the "cognitive effort" required to understand the other is relatively small.

Explicitly introducing what we have called cognitive effort resembles the introduction of bargaining costs in bargaining theory. As the Coase theorem states, two parties will find an efficient solution to a given bargain if bargaining costs are absent. Similarly, Smith spoke of a "harmony of minds" which can be obtained if "free communication of sentiments and

\footnotetext{
14 The term "cognitive effort" should of course not imply that we consciously engage in imagining the others
} position. 
opinions" is given (TMS, VII.iv.28). But sentiments are communicated via sympathy and are thus subject to cognitive effort. The ideal can only be obtained under ideal conditions, which are not predominant in the real world.

Apparently, there exists a trade-off between the positive and the negative effects of homogeneity. On the one hand, homogeneity facilitates the communication and therefore the flow of information within a group. This effect renders the impartiality of the group as a whole possible. As in all cases of team work, the ensemble has to work together. This presupposes a certain degree of mutual respect and understanding. In different words, sympathy (in the strong form) is already necessary in order to facilitate sympathy and achieve agreement. On the other hand, homogeneity limits the amount of attitudes and information represented within the group. This effect impedes reaching an impartial perspective. The members of the ensemble may enjoy each other's presence so much that they neglect to play their roles.

Furthermore, the Jury Theorem assumes "good actors": each juror is more likely than not to make the correct choice. However, there is evidence that in real life this assumption is not met. Tullock (2005: 468) argues that over $60 \%$ of the summoned jurors in the USA successfully get around their duty. "Juries typically consist, therefore, of individuals of below average intelligence, below average income and below average productivity. They are made up disproportionately of the old, the lame and the unemployed. They are selected to reflect racial and ethnic diversity and implicitly encouraged, therefore, to think of their role in such terms." And he continues that, "as general rule they [the members of a jury] do not know the law, and the judges' instructions are normally confusing. If they did know the law they would still be likely to follow their own ethical principles even if they conflicted with the law" (Tullock 1998: 399f.). Consequently, the knowledge of jury members - at least in the USA is interpreted as not being sufficient to speak of a high probability that they make the correct choice. This sounds reasonable, at least if the probability of making the correct choice is correlated with the kinds of knowledge stated by Tullock. Consequently, the verdicts of these juries may fail to come to "true" judgements.

\section{Back to Stage and the Backstage}

The jury as legal institution is surely highly debated. From an abstract point of view we have mostly argued in favour of it. If one accepts Smith's description of a moral judgement process, the jury could be preferable to other forms of legal settlement as the legal procedure resembles the moral procedure. Consequently, a legal procedure based on juries 
could be regarded as "natural", possibly leading to support from the society. Moreover, the jury as quasi-spokesman of the society gives every member of the society a certain degree of influence on the legal system. "[T]he suggestion is that the action of the courtroom, as a type of theatre, is an image of the manner in which citizens are to have parts of importance and dignity, to be taken seriously and with ceremonious, protective deference, and to have their rights and duties fairly recognized" (Ball 1975: 113). Thus, each member will tend to feel represented by this system, and therefore give assistance and support to it. As Tocqueville (1956 [1835/40]: 32) observed: "I can conceive of a society in which all men would feel an equal love and respect for the laws of which they consider themselves as the authors; in which the authority of the government would be respected as necessary, though not as divine and in which the loyalty of the subject to the chide magistrate would not be a passion, but a quiet and rational persuasion."

The process of finding approval, paired with the idiosyncratic knowledge derived from individual sympathy with the subjects to the court makes the finding of a common standpoint necessary. This common standpoint can be interpreted as that of a third person, an impartial spectator. In order to guarantee that this third person is not biased towards either of the parties a collective of judges will be formed that can be regarded as a representation of the society's impartial spectator and of its value system. The impartial spectator is the main actor on the judicial stage of society. It may seem noteworthy that even a rather strict critic of the jury as legal institution, Gordon Tullock, admits that "[i]f what one is trying to do is to produce the democratic outcome, i.e., the outcome which the people as a whole would vote for if they were given a chance, the jury is an excellent technique" (Tullock 1998: 398f.).

However, sometimes the play may misdirect the audience. "The courts may fail to offer an image of the political community by turning in upon themselves, thereby either creating too great a distance from the human realities they are to mirror or overemphasizing the theatrical trappings so that dress and decorum become precious objects in themselves. The courts may also fail to reflect the correct image - the image not of the political community as it legitimately and really is but as it may appear at any present moment when seized by 'ill humors'. In this latter circumstance judicial masks conceal rather than amplify grievances, and oppression is hidden from view and extended into the courtroom" (Ball 1975: 113f.).

In other words, in order for the jury system to work well, good legal actors are required. These actors have to be able to rely on their "individual" impartial spectator in order to fully extract the potential of the system. But sometimes laymen may confuse reality with the theatricality of the play. They might be good actors, but forget to rely on their impartial 
spectator. As Hollis (1985: 222) notes, we "may be inclined to view actors as donning and doffing masks like hats but that is not the only way to conceptualize theatre. Acting can also be regarded less as representation than as expression. This may not seem plausible for village hall theatricals but it rings truer for professional acting..." Therefore, a good actor has to learn to integrate "his personality", his interpretation of the role. For the juror this implies that he has to learn to call on his impartial spectator, something that seems rather difficult for "village hall" actors. In legal theatre, merely representing instead of expressing may alter the verdict. For instance, one could argue that the propensity to call for severe punishments increases. It adds to the dramaturgy and is therefore fun, or so the jurors might believe, not realizing the reality behind their verdict.

Given the analysis above, the quality of the actors, their ability to express instead of representing, depends on their practice in sympathizing with each other. One way to increase the possibilities of practicing sympathy is to provide arenas for practice, such as the theatre. That could be one of the reasons for public support to the theatre. For instance, Jenkins and Austen-Smith (1987) report grants of 50-60\% of the budget of English provincial theatres and Krebs and Pommerehne (1995) report that the share of governmental subsidies to total income of German theatres amounts roughly $85 \%$.

A vivid example of how theatre may affect the well-being of a society (and, as was hinted at in the introduction, how the distinction of actors and audience may get blurred) is given in Ramirez (1991). He reports of a theatre project that involves 650 actors, including 50 horsemen, playing 3.225 roles in a two-hour show. The stage is of 12 hectares and includes a castle and a pond. More than 1.700 inhabitants of Saint-Malo-du-Bois, Le Beaupere, and a dozen neighbouring villages helped to put on stage, twice each week-end throughout the summer. About 11.000 spectators attend each show. The responsibility of this event is with the Association pour la Mise en Valeur du Pays et la Château du Puy du Fou in Vendée, France.

After having visited the event in 1984 and 1986, also participating in its preparation, Ramirez (1981: 85) concludes that while "... attracting tens of thousands of spectators a week over the summer, the people who benefit most from the existence of the Association are without a doubt the over 1.700 members the Association ..." He points out that the "Association and its activities simultaneously preserve and develop the identity of many Vendeans. It expresses it and in a way defines the way it manifests itself, shaping it in the mind of many of the organization's stakeholders." It seems that there is a need for identity and the participants feel like this. 
The play stages the history of Puy du Fou from the Middle Ages to World War II. La Vendée "is something like a historic aberration in France." Its history "does differentiate it from what happened in most of the rest of France" (ibd. 81). The rebellion against the newly established Republic following the French Revolution and the execution of Louis XVI "gave the Vendeans a reputation for being pro-monarchic that has survived to this day" (ibd. 81). Finally, in winter 1794, the Republican army crushed the Vendée rebels. The consequence was massive repressions which involved the shooting of thousands of rebels, "pillaging, ransacking, raping, and destroying much of Vendée, including the castle at Puy du Fou " (ibd. 82). This turned the Vendée into a thinly populated agricultural region and to remain like this for almost two centuries. There is something like "healing" in this theatre project and the wide-spread participation. ${ }^{15}$

Thus, theatre may not only contribute to an ethical maturation of the society as Nussbaum (1996) found. It may also contribute to the "quality" of its legal institutions. And, as our above analysis may have shown, these legal institutions may in turn add to the ethical maturation again. Given its theatrical dimension and its practice of empathy, a jury system has the potential to lead to an ethical maturation of the society as well. However, this potential is combined with a greater risk if the actors are only weak performers. To the best of our knowledge, this specific, theatrical link between morality and the law adds a new argument to the discussion surrounding the use of juries.

\section{References:}

Aeschylus (1979), The Oresteia, translated by Robert Fagles, New York et al.: Penguin Books.

Bagolini, Luigi (1975), “The Topicality of Adam Smith's Notion of Sympathy and Judicial Evaluations", in: Skinner, Andrew S. and Thomas Wilson (eds), Essays on Adam Smith, Oxford: Clarendon Press: 100-113.

Ball, Milnor S. (1975), “The Play's the Thing: An Unscientific Reflection on Courts Under the Rubric of Theater", Stanford Law Review 28(1): 81-115.

\footnotetext{
15 There is however a second story to it. According to Ramirez (1991: 86), the Association provided Phillipe de Villier "with the platform from which he launched his career as politician in the National arena." De Villier was the most influential actor at Puy de Fou and the key organizer of the event in its beginning. When on March 16, 1986, Jacques Chirac became Prime Minister he was named Secretary of State (i.e., junior minister) for Culture and Communications.
} 
Bentley, Eric (1966), “The Science Fiction of Bertolt Brecht”, Galileo, New York: Groves Press.

Berg, Sven (1993), “Condorcet's Jury Theorem, Dependency among Jurors”, Social Choice and Welfare 10: 87-95.

Darwall, Stephen (1999), "Sympathetic liberalism: Recent work on Adam Smith,” Philosophy and Public Affairs 28: 140-163.

Fagles, Robert (1979), “A Reading of 'The Oresteia' - The Serpent and the Eagle”, in: Aeschylus (1979), The Oresteia, translated by Robert Fagles, New York et al.: Penguin Books.: 1-99.

Griswold, Charles (1999), Adam Smith and the Virtues of Enlightenment, Cambridge: Cambridge University Press.

Griswold, Charles L. (2006), "Imagination: Morals, Science, and Arts”, in: Haakonssen, Knud (ed.), The Cambridge Companion to Adam Smith, Cambridge: Cambridge University Press: 22-56.

Grofman, Bernard and Scott L. Feld (1988), "Rousseau's General Will: A Condorcetian Perspective", The American Political Science Review 82: 567-576.

Hart, Herbert L.A. (1958), "Positivism and the Separation of Law and Morals", Harvard Law Review 71(4): 593-629.

Holler, Manfred J. (2006), “Adam Smith's model of man and some of its consequences”, Homo Oeconomicus 23, 467-488.

Holler, Manfred J. and Martin Leroch (2008), "Impartial Spectator, Moral Community, and Some Legal Consequences", Journal of History of Economic Thought (forthcoming).

Hollis, Martin (1985), "Masks and Men”, in: Carrithers, Michael, Steven Collins and Steven Lukes (eds), The Category of the Person: Anthropology, Philosophy, History, Cambridge: Cambridge University Press: 217-233.

Jenkins, Stephen and David Austen-Smith (1987), "Interdependent decision-making in nonprofit industries: A simultaneous equation analysis of English provincial theatre", International Journal of Industrial Organization 5: 149-174.

Khalil, Elias (2007), "The Mirro-Neuron Paradox: How Far is Sympathy from Compassion, Indulgence and Adulation?”, MPRA Paper No. 3961, available: http://mpra.ub.unimuenchen.de/3961/ 
Krebs, Susanne and Werner W. Pommerehne (1995), "Politico-economic interactions of German public performing arts institutions", Journal of Cultural Economics 19: 17-32.

Levit, David M. and Sandra J. Peart (2004), "Sympathy and Approbation in Hume and Smith: A Solution to the other Rational Species Problem", Economics and Philosophy 20: 331-349.

Nussbaum, Martha (1996), “Compassion: The Basic Social Emotion”, Social Philosophy and Policy 13: 27-58.

Ramirez, Rafael (1991), The Beauty of Social Organization, Munich: Accedo Publishing.

Raphael, David D. (1975), “The Impartial Spectator”, in: Skinner, A. and T. Wilson (eds), Essays on Adam Smith, Clarendon Press: 83-99.

Rawls, John (1972), A Theory of Justice, London et al.: Oxford University Press.

Scanlon, Thomas M. (1999), What We Owe to Each Other, Cambridge (Mass.) and London: The Belknap Press of Harvard University Press.

Smith, Adam (1979 [1776/77]), An Inquiry into the Nature and Causes of the Wealth of Nations, ed. by R.H. Campbell and A.S. Skinner, Indianapolis: Liberty Press.

Smith, Adam (1982 [1759, 1790]), The Theory of Moral Sentiments, ed. by D.D. Raphael and A.L. Macfie, Indianapolis: Liberty Press.

Smith, Adam (1982 [1762-1766]), Lectures on Jurisprudence, ed. by R.L. Meek, D.D. Raphael and P.G. Stein, Indianapolis: Liberty Press.

Smith, Adam (1983 [1762-1763]), Lectures on Rhetoric and Belles Lettres, ed. by J.C. Bryce and A.S. Skinner, Indianapolis: Liberty Press.

Sunstein, Cass (1999), The Law of Group Polarization", University of Chicago, John M. Ohlin Law \& Economics Working Paper No. 91 ( $2^{\text {nd }}$ series).

Sutrop, Margit (2007), “Adam Smith on Sympathy and Moral Motivation”, Acta Philosophica Fennica 83: 143-168.

Tocqueville, Alexis de (1956 [1835/40]), Democracy in America, ed. by T.D. Heffner, New York and Toronto: Mentor Books.

Tullock, Gordon (1998), “Juries”, in: Newmann, P. (ed.), The New Palgrave Dictionary of Economics and the Law, London: Macmillan Reference Limited: 395-400. 
Tullock, Gordon, (2005), "The case against the common law", in: Parisi, Francesco and Charles K. Rowley (eds), The Origins of Law and Economics, Cheltenham and Northampton: Edward Elgar: pp. 464-474. 